\title{
AN ETHNO MEDICAL SURVEY ON THE TRADITIONAL MEDICINES AND METHODS USING FOR THE TREATMENT OF ARSHAS (HAEMORRHOIDS) IN SRI LANKA
}

\author{
Research Article
}

\begin{abstract}
Kumudu Rupika Weerasekera $^{1 *}$, Sujatha Ediriweera ${ }^{2}$, Cooray Vidyashekera ${ }^{3}$.
1. Senior Lecturer, 2. Professor, Department of Nidana Chikitsa, 3. Former Director, Institute of Indigenous Medicine, University of Colombo.
\end{abstract}

\begin{abstract}
Back ground: Arshas (Heamorrhoids) is one of the most common ailments in Sri Lankan society. Most of the people suffering from Arshas have great faith in Ayurvedic and Traditional treatments. According to literature survey there are many preparations for the Arshas done by using herbs and materials which could be found from our natural surroundings. The traditional medical practitioners' select the drugs based on a rational theory and empirical knowledge obtained by trial and error. Some traditional physicians of Sri Lanka claim to have special treatments known only to them or to the trusted members of the family, or the most eminent and trusted of the physician. Objectives: This survey conducted to find out the most using formulations, treatment methods and commonest drugs used for the disease of Arshas of the traditional physicians in Sri Lanka. Methods: In this survey ethno medical data was collected from thirty four traditional physicians residing in Uva province in Sri Lanka by using a questioneer. Results: The main methods of treating the disease Arshas was Kashaya (Decoctions), Churna (Powders), Alepa (Pastes), Avagaha (Sitz baths), Arishta, Asava and Dhuma (fumes). The most common herbs of treating the Arshas were Gotukola (Centella asiatica L.), Kohila (Lassia spinosa L.), Mun (Vigna radiate), Umbalakada (Maldive fish) and Ratu Araliya (Plumeria autifoloa P.).
\end{abstract}

Key words: Arshas, Traditional Treatment, Ethno medical, Sri Lanka

\section{Introduction}

Arshas is a major affliction that affects the human society. Arshas are extremely common in adults (1). In Ayurveda, ancient physicians and surgeons described Arshas as an abnormal fleshy growth in ano rectal region (guda) (2). Arshas are correlated with haemorrhoids in western

\footnotetext{
*Corresponding Author:

K.R Weerasekera,

Department of Nidana Chikitsa,

Institute of Indigenous Medicine,

University of Colombo,

Rajagiriya, Sri Lanka.

E-mail: kumuduweerasekera@yahoo.com

Phone: +94 718476621
}

modern medicine. The main symptoms of the haemorrhoids are bleeding, prolapsed, discharge and pain (3). In western modern medicine haemorrhoids are treated by several methods. These include chemotherapy, reduction of sphincteric pressure, fixation treatment and surgical treatment (3). In Sri Lanka in traditional medicine, Arshas is called Mulaggaya (4) and the traditional physicians are using several methods to treat Arshas including application of herbal oils, pastes and internal medicines. The aim of this study was to find out various traditional medicines, methods and most consuming herbs for the medicines using in traditional physicians in Sri Lanka for the disease of Arshas. 


\section{Material and methods}

The study was done in Uva province in Sri Lanka and ethno medical data was collected by using a questioner from thirty four well known traditional physicians residing in Uva province.

\section{Results and observations}

(1). Below mentioned recipes are the most regularly prescribe recipes by all 34 traditional physicians. These recipes are selected after the evaluation of traditional physicians' treatment prescriptions. A selected criteria of these prescriptions was, this one recipe is using more than 10 traditional physicians. The prescriptions quoted by physicians who participated in the survey are given below with Sinhalese name and botanical name.

i. Entire plant of Gotukola (Centella asiatica L.), Bulbs of Ratulunu (Allium cepa L.), Spadix of Kohila (Lassia spinosa L.), Seeds of Mun (Vigna radiate L.) and Umbalakada (Maldive fish) - decoction.

ii. Roots of Savandara (Vetiveria zizanioides L.), barks of Kohomba (Azadirachta indica A.) and Kurundu (Cinnamomum seyalanicum B.), Stems of Venival (Coscinium fenestratum G.) decoction.

iii. Roots of Diyamitta (Cissmpelos pareira L.) and seeds of Asamodagam (Trigonella foenum L.) -decoction.

iv. Roots of Diyamitta (Cissmpelos pareira L.) and Kahabiliya (Tragia plukenetti R.) - decoction.

v. Decoction prepared with Roots of Nidikumba (Desmodium triflorum L.) with adding Ghee.

vi. Rhizome of Inguru (Zingiber officinale L.), Roots of Beli (Aegle marmelos L.) and Ratnitol (Plumbago indica L.) - decoction.

vii. Roots of Mukunuwenna (Alternanthera sessilis L.) and seeds of Mun (Vigna radiate L.) decoction.

viii. Latex of Imbul (Ceiba pentandra L.), Rhizome of Manel (Nymphaea nouchali F.), Roots of Nidikumba (Desmodium triflorum L.), Seeds of Tala (Sesamum indicum L.), Stem of Suduhadun (Santalum album L.) - decoction.

ix. Entire plant of Gotukola (Centella asiatica L.), Bulbs of Ratulunu (Allium cepa L.), Spadix of Kohila (Lassia spinosa L.) - decoction.

x. Leaves of Ratu Araliya (Plumeria autifoloa P.) - decoction.

xi. Entire plant of Gotukola (Centella asiatica L.), Bulbs of Ratulunu (Allium cepa L.), Spadix of Kohila (Lassia spinosa L.) and seeds of Sududuru (Cumunum cyminum L.) - decoction.

xii. A decoction prepared with Spadix of Kohila (Lassia spinosa L.), Rhizome of Alukesel (Musa paradisiacal L.), Inner pith of Vatakeiya (Pandanus kaidan L.), Umbalakada (Maldive fish) with Jaggary.

xiii. Equal portion of Heerassapalu (Cissus quadrangularis L.), Leaves of Olinda (Arbus melanospermus L.), Entire plant of Gotukola (Centella asiatica L.), Roots of Karalhaba (Achyranthes aspera L.) and Karanda (Pongamia glubra and Vent) are taken and the juice is extracted. This extracted juice is given in treatment of piles.

xiv. 10 kalan $(5 \mathrm{~g})$ of Seeds of Badulla (Semecatpus coriacea T.), 20 kalan of plant of Sarana (Boerhavia diffusa L.) and roots of Ratnitol (Plumbago indica L.), 5 kalan of seeds of Tippili (Piper longum L.) are taken and grounded together with equal weight of Jaggary to make a paste. This paste is taken orally twice a day, $5 \mathrm{~g}$ at a time. 
XV. Stamens of flowers of Nelum (Nelumbo nucifera L.) are mixed with Bee honey and Ghee and given in treatment of piles.

xvi. The kanji prepared from stem bark of Ratnitol (Plumbago indica L.) and scraped kernel of King coconut is given in treatment of piles.

xvii. Seeds of Kalutala (Sesamum indicum L.) are ground with water and apply on piles.

xviii. Leaves of Karavila (Momordica charantia L.), Bulbs of Sudulunu (Allium sativum L.), Chimney soots are taken in equal quantity and grounded together. This applied on pile masses.

xix. Forment the pile masses with heated shell of tortes.

xx. Powdered sugar candy is sprinkled on embers obtain by burning coconut shells. The piles fumigated from the arising smoke.

xxi. Leaves of Val Inguru (Zingiber cassumunar R.) and Human hair are put in to fire and fumigate the piles.

xxii. Bulbs of Ratulunu (Allium cepa L.) are grounded and made in to a bolus using a piece of cloth. This bolus is heated using steam and pile masses are fomented with this.

xxiii. $\quad 10 \mathrm{~g}$ each of Savinda lunu (Sodium chloride impure), Kalu tumba (Momordica dioica R.), Datta (Baliospermum montanum M.), Kaneru (Nerium indicum M.), Bin kohkmba (Pongamia pinnata L.), Valangasahal (Embelia ribes L.) are taken and 4 nali of water is added and is made into a decoction by boiling down to 1 nali. The same ingredients are taken again in similar quantity and ground in to a fine powder. This powder is added to the afore said decoction along with one patha of latex obtain from Vara (Calotropis gigantean L.) and 1 nali of Talatel (oil of Sesamum indicum L.) was added. The whole mixture is then boiled according to thaila paka and the oil obtain is applied on the piles.

xxiv. Kohila ala juice (spadix of Lassia spinosa L.) 8 nali, Thumba karavilla juice (Juice of tuberous root of Momordica dioica R.) 4 nali, Kidaran ala juice (juice of corms of Amorphallus companulatus D.) 2 nali, Gingerly oil 1 nali and 5 kalan each of Seenakkaran (Potash Alum), Vedi lunu (Potassium Nitrate), Inguru (Zingiber officinale R.), Gammiris (Piper nigrum L.), Tippili (Piper longum L), Mee mini mavil (skin hair of mouse deer), Badulla eta (seeds of Semecarpus anacardium L.f.), Daluk eta (seeds of Euphorbia antiquarum L.), Perumkayam (Ferula asafetida L.), Galis (Gardenia gummifera L.) and make an oil and applied as a pitcu into the anal canal.(2). The methods of treatment for Arshas as described by the physicians are given in below table 1 .

Table 1: Methods of treating Arshas

\begin{tabular}{|l|c|c|}
\hline \multicolumn{1}{|c|}{ Method } & No. of physicians & Percentage (\%) \\
\hline Kasaya (Decoction) & 34 & 100 \\
\hline Churna (Powder) & 34 & 100 \\
\hline Guli (Pills) & 18 & 53 \\
\hline Kalka (Paste) & 22 & 65 \\
\hline Arista/ Asava & 32 & 94 \\
\hline Thaila - Pitchu & 8 & 23 \\
\hline
\end{tabular}




\begin{tabular}{|l|c|c|}
\hline Thaila - Vasti & 4 & 12 \\
\hline Thaila - Application & 34 & 100 \\
\hline Vidum (Accupuncture) & 0 & 0 \\
\hline Pillissum (Cortarization) & 0 & 0 \\
\hline Kshara(Cortarization) & 4 & 12 \\
\hline Shalya (surgical methods) & 0 & 0 \\
\hline Avagaha (Sitz bath) & 34 & 100 \\
\hline Thavili (fomentation) & 20 & 58 \\
\hline Dhuma (Fume) & 14 & 41 \\
\hline Mantra (Hymn) & 4 & 12 \\
\hline $\begin{array}{l}\text { Kem karma (Secret methods } \\
\text { of traditional treatments) }\end{array}$ & 8 & 23 \\
\hline
\end{tabular}

(3). All the prescriptions and treating methods of 34 traditional physicians are carefully studied and below mentioned plants were the only plants including all prescriptions prescribe for the treatment of Arshas. Those using plants and the method used are given in table 2.

Table 2: Plants used in treatment of Arshas and the method used

\begin{tabular}{|c|c|c|c|c|c|c|c|}
\hline \multirow{2}{*}{ Sinhala name } & \multirow{2}{*}{ Botanical name } & \multirow[b]{2}{*}{ 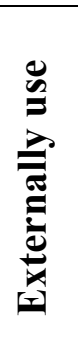 } & \multicolumn{5}{|c|}{ Internally use } \\
\hline & & & & 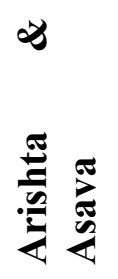 & $\stackrel{0}{\bar{E}}$ & 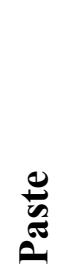 & 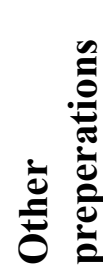 \\
\hline Aralu & Terminalia chebula $\mathrm{R}$. & + & + & + & + & + & + \\
\hline Bulu & Terminalia belarica R.- & - & + & + & + & + & + \\
\hline Nelli & Emblica officinalis $\mathrm{G}$. & - & + & + & + & + & + \\
\hline Kohila & Lassia spinosa L. & + & + & - & - & - & - \\
\hline Ratkarala haba & Achyranthes aspera L. & - & + & - & - & - & - \\
\hline Vara & Calotropis gigantic L. & + & - & - & - & - & + \\
\hline Daluk & Euphorbia antiquorum L. & + & - & - & - & - & - \\
\hline Gotukola & Centella asiatica $\mathrm{L}$ & + & + & - & - & - & + \\
\hline Namal renu & Mesua fera L. & + & + & - & - & + & + \\
\hline Ratu araliya & Plumeria acutifolia $\mathrm{P}$. & - & + & - & - & - & - \\
\hline Undupiyaliya & Desmodium triflorum D. & + & + & - & - & - & - \\
\hline Vel penela & $\begin{array}{l}\text { Cardiosprmum } \\
\text { halicacabum } \mathrm{L} \text {. }\end{array}$ & + & + & - & - & - & - \\
\hline Uk mul & Saccharum officinarum L. & - & + & - & - & - & - \\
\hline Kidaran & $\begin{array}{l}\text { Amorphophilus } \\
\text { companilatus D. }\end{array}$ & + & + & - & - & - & + \\
\hline Beli & Aegle marmelos $\mathrm{C}$. & - & + & - & - & - & + \\
\hline Kalu tala & Sesamum indicum L. & + & + & - & - & - & - \\
\hline Sudu handun & Santalum album L. & - & + & - & - & - & + \\
\hline Badulla & $\begin{array}{l}\text { Semecarpus anacardium } \\
\text { L. }\end{array}$ & + & + & - & - & - & - \\
\hline Ratu lunu & Allium cepa $\mathrm{L}$. & + & + & - & - & - & + \\
\hline
\end{tabular}




\begin{tabular}{|c|c|c|c|c|c|c|c|}
\hline Kaladuru & Cyperus rotandus L. & - & + & + & + & + & + \\
\hline Kalu thumba & Momordica dioica $\mathrm{R}$. & + & + & - & - & - & - \\
\hline Hin nidikumba & Biophytum sansitivum Dc. & + & + & - & - & - & + \\
\hline Val inguru & Zingiber cassumunar R. & - & + & - & - & - & - \\
\hline Muruva & Marsdenia tenacissima $\mathrm{R}$. & - & + & - & - & - & - \\
\hline Asamodagam & Trigonella foenum L. & - & + & - & - & - & - \\
\hline Savandara & Vetiveria zizanioides L. & + & + & + & - & - & - \\
\hline Eth thora & Cassia lata L. & + & + & - & - & - & - \\
\hline Olinda & Abrus precatorius L. & + & + & - & - & - & - \\
\hline Heerassapalu & Cissus quadrangularis L. & + & + & - & - & - & - \\
\hline Imbul & Salmalia malabartica $\mathrm{S}$. & - & + & - & - & - & - \\
\hline Abin & Papaver somniferum L. & - & + & + & + & + & - \\
\hline Rath nitol & Plumbago indica L. & + & + & - & - & - & - \\
\hline Mukunuwanna & Alternanthera Sessilis L. & + & + & - & - & - & - \\
\hline Karawila & Momordica charantia L. & - & + & - & - & - & + \\
\hline Vatakeiya & Pandanus tectorius $\mathrm{S}$. & - & + & - & - & - & - \\
\hline Bin kohomba & Munronia pinnata & - & + & - & - & - & - \\
\hline Kottamalli & Hyoscyamus reticulates L. & - & + & + & + & + & - \\
\hline Palol & $\begin{array}{l}\text { Stereosperum suaveolens } \\
\text { DC. }\end{array}$ & - & + & - & - & - & - \\
\hline Vel kappetiya & Croton lacciferusa & + & + & - & - & - & - \\
\hline Nika & Vitex nigando L. & - & + & - & - & - & - \\
\hline Diyamitta & Cissampelos Pereira L. & + & + & - & - & - & - \\
\hline Venivel & Coscinium fenestratum $\mathrm{G}$. & - & + & - & - & - & - \\
\hline Inguru & Zingiber officinale R. & - & + & + & + & + & - \\
\hline Alu kesel & Musa paradisiacal L. & - & + & - & - & - & - \\
\hline Manel & Mymphaea lotus L. & + & + & - & - & - & - \\
\hline Divul & Feronia limonia L. & - & + & - & - & - & - \\
\hline
\end{tabular}

\section{Discussion}

The traditional medical field has many methods of treatment for treat the disease of Arshas.

All 34 physicians were use Kashaya (Decoctions), Churna (Powders), application of oil and Avagaha (Sitz baths). Arishta and Asava are using 32 physicians. Kalka (Paste), Guli (Pills) and Thavili ( Formantation) are used 22, 20 and 18 physicians respectively. Dhuma (Fumes) are practice 14 physicians and Thaila pichu and Kem karma (Secret methods of traditional treatments) are 8 physicians were prescribes. Mantra (Hymn), Thaila vasti and Kshara (Coutarization) are only 4 physicians are practice. Vidum (Accupuncture), Pillissum (Cortarization) and Shalya (surgical methods) are currently not practice. 46 plants are identified to use the treatment for Arshas and some plants are using externally and some are internally. Some plants are use externally and internally both. Chimney soots, shell of tortes, coconut shells, Human hair and skin hair of mouse deer also included the treatments. For the decoctions Gotukola (Centella asiatica L.), Kohila (Lassia spinosa L.), Mun (Vigna radiate L.), Umbalakada (Maldive fish) and Ratu Araliya (Plumeria autifoloa P.) are also popular among the traditional physicians. 


\section{Conclusion}

The traditional physicians of Sri Lanka use many methods to treat the disease Arshas but currently the treatment methods are limited such as Kashaya (Decoctions), Churna (Powdwes), Alepa (Pastes), Avagaha (Sitz baths), Thavili (fomentation), Arishta, Asava and Dhuma (fumes) and they do not practice Agni (coutarization) and Shastra (Surgery) as a treatment method. Some physicians are using Mantra (Hymn) and Kem karma (Secret methods of traditional treatments) as a treatment and they practice these methods along with medicaments. In traditional medicine, exceptional plant and animal materials are also use for treat Arshas. Most physicians seem to be quoting the commonest and well known prescriptions.

A common difficulty encountered during this study was the unwillingness of the physicians to divulge the best prescriptions and treatment methods used most successfully by them, specially the prescriptions which come down in the family.

\section{References:}

1. Haslett C, Chilvers E.R, Hunter J.A.A, Boon N.A, Davidson's Principles and Practice of Medicine, $18^{\text {th }}$ edi, Churchill Livingston, 2000; pp 680.

2. Murty K.R.S, Astanga hrdayam, Vol II, Varanasi, India Krishnadas acdemy, 2000; pp66.

3. Forrest A.P.M, Carter D.C, Macleod, Principals and Practice of Surgery; $3^{\text {rd }}$ edi; Churchill Livingston, 1990;p456458.

4. Deshiya Chikitsa Samgrahaya, Department of Ayurveda, Colombo, Sri Lanka; 1984: pp391. 